Second Bwanakare

Non-Extensive Entropy Econometrics for Low Frequency Series

National Accounts-Based Inverse Problems 

Second Bwanakare

\section{Non-Extensive Entropy Econometrics for Low Frequency Series}

National Accounts-Based Inverse Problems

Managing Editor: Konrad Sarzyński

Language Editor: Naguib Lallmahomed 
Published by De Gruyter Poland Ltd, Warsaw/Berlin

Part of Walter de Gruyter GmbH, Berlin/Boston

The book is published with open access at www.degruyter.com.

\section{(cc) BY-NC-ND}

This work is licensed under the Creative Commons Attribution-NonCommercial-NoDerivs 4.0 License. For details go to http://creativecommons.org/licenses/by-nc-nd/4.0/.

\section{Library of Congress Cataloging-in-Publication Data}

A CIP catalog record for this book has been applied for at the Library of Congress.

\section{Second Edition}

Copyright $\odot 2018$ Second Bwanakare

ISBN: 978-3-11-060590-7

e-ISBN: 978-3-11-060591-4

Bibliographic information published by the Deutsche Nationalbibliothek. The Deutsche Nationalbibliothek lists this publication in the Deutsche Nationalbibliografie; detailed bibliographic data are available in the Internet at http://dnb.dnb.de.

Managing Editor: Konrad Sarzyński

Language Editor: Naguib Lallmahomed

www.degruyter.com

Cover illustration: () Thinkstock, Credit: liuzishan 
To my wife Rose and my daughter Ozane for their many sacrifices 
